ISSN 1112-9867

Available online at

http://www.jfas.info

\title{
RISK MANAGMENT IN LSF STRUCTURES (IDENTIFYING, ASSESSMENT, RESPONDING)
}

\author{
A. Yegane ${ }^{1}$ and H. Shariatmadari, ${ }^{2, *}$ \\ ${ }^{1}$ MA Construction Engineering Student of Ferdowsi University of Mashhad, Mashhad, Iran \\ ${ }^{2}$ Associated Professor, Department of Construction Engineering, Ferdowsi University of \\ Mashhad, Mashhad, Iran
}

Published online: 05 June 2016

\begin{abstract}
Light Steel Frame System that is briefly called LSF is a building system which is used for implying of short-rise and mid-rise buildings (up to 5 floors). It's a desirable building system for civil engineers (in terms of gravity and lateral load) in developed countries. Despite the relatively significant growth of LSF structures during the last decade in our country, the studies in this field have been still done neither in our country nor in abroad. In this article, we try to study LSF structures from the design and implementation stages to the operation one and identify its risks exactly and finally offer a solution with classifying and prioritizing them.
\end{abstract}

Keywords: LSF structures; risk management; identifying risk; classifying risk; assessment of risk; respond to risk.

Author Correspondence, e-mail: shariatmadar@um.ac.ir

doi: http://dx.doi.org/10.4314/jfas.8vi2s.53

\section{INTRODUCTION}

On of the building systems that have had appropriate development at the global level in the last years is cold-rolled light steel building system. This system is one of the systems that although its origin is rooted in environmental concerns, and consequently there have been definition of alternative option for wooden structures, but it has gradually found a special 
position among the systems with industrial production capacity. Along with desire to develop building industrialization in the country, performing single-production and mass-production projects with cold-rolled light steel pieces has also promoted and according to high production capacity of steel in the country and advantages such as high flexibility, low weight of the structure and appurtenant and fast production method has caused that cold-rolled light steel buildings become a notable option in building construction industry in the country.

The most researches in this field have examined LSF in terms of structure and also comparison with the traditional structures. Of course on the aspect of cost, time and quality, LSF structures have been examined compared with iron skeleton structures; but it's not been done any special study in the field of risk management in LSF structures. Since LSF projects usually used for adding the floors and constructing villas in our country, they have small scales and that why we increase our own samples to get to the desirable results.

There are different methods of risk analyze that three techniques: FMEA, AHP (Analytical Hierarchy Process) and fuzzy have been more used. We use FMEA techniques to identify the risks by questionnaire; because our subjects are usually supervisor engineers and executive forces. Since the executives forces of LSF structures are mostly specialists, they can acceptable relate to the possible concepts. After identifying the risks by FMEA technique, we analyze them using fuzzy method. Since AHP method has a long history and also it's not a hard method, we'll get help from this method and compare the results with the pervious state.

The above operations, in the form of a model have been suggested in a student's MA thesis in Amirkabir University of Technology for construction projects. In this study, It's been suggested we implement the same model with the permission of author.

\section{THE INTRODUCTION OF LIGHT STEEL FRAME}

\subsection{Production method}

Light steel frame system with abbreviated name of LSF is made of cold -rolled steel sections or CFS. It's been widely used about 20 years in industrial production of office, commercial and residential buildings and has had a special place in developed countries as an appropriate substitute for traditional construction methods.

$\mathrm{U}$ and $\mathrm{C}$ sections are used in this system which is connected to each other with cold joints. Each wall is made up of a number of public c-shaped components to a distance of 40 to 60 $\mathrm{cm}$. in most cases, this system implements with light roof and with the other type of roofs. 
Rafters and beams of this type of light roofs are like wall's master and tracks. The last roof is usually constructed steep using metal trusses made of cold rolled profiles.

\subsection{LSF System Advantages}

LSF system has the advantages of high speed performance, lightness of building weight, earthquake-resistant, savings in energy consumption, ease of maintenance and repair, existence of raw materials within the country, possibility of modularization and standardization, possibility of prefabrication of panels, possibility of producing pieces in place of implementation, ease of implementation of electrical and mechanical installations, compliance with common building regulations, accurate structural calculations for the forces, observance of all heating and cooling energy waste issues, variety of designing and producing the building with adifferent facades according to the request of employers and coordinate with local architecture, permanent use as a building with high durability and similar to traditional buildings, quick return of initial investment, environmental compatibility, and observence of principles of sustainable construction, durability and stainability of the structure, and increase of shelf life of the building [8].

New research on the seismic behavior of LSF structures shows that the use of these structures in regions with intense seismicity improves seismic behavior [9].

\subsection{LSF system disadvantages}

LSF system has disadvantages such as low resistance against fire of wall insulation core, complexity of modeling thermal performance because of the presence of several types of materials, weakness against strong wind, shortage of expert executive force, risk of noise creation during the expansion and contraction of the structure, unknown structural behavior of the system in the country, higher prices than traditional materials in countries where this system has not spread, and height restriction [10].

\section{IDENTIFICATION OF RISK IN LSF STRUCTURES}

In this part, we study the process of risk identification. For sure, this part is one of the most important stages of implementation of this study; because if the risks are not identified successfully, then the other results will not be reliable.

There are risks or risk factors in all industries. Factors such as prior knowledge, individual skills and experience can help in detecting such risk. The results change considering that through which way the information has been collected, and a range of people have involved in collecting it [10]. The information used in risk identification process may include cases such 
as, historical information, historical analysis, the view of project team, and concerns of the beneficiaries [11].

There are several ways to identify risks. the interview method was applied for this research among the mentioned method. Other techniques were not applied for reasons such as lack of project management team, lack of need for consensus, lack of need for keeping the interviewee information secret, and so on.

LSF structures are not usually performed in large-scale in our country. For example, only two mass-production projects in Binaloud and Gherghi have been implemented by LSF method in Mashhad city and countryside, and the other projects usually have not significant infrastructure. That is why it has been attempted in this research to increase the study cases in order to increase the accuracy and reliability of the data. This means that although each project has no significant infrastructure, but total examined infrastructure is reliable. Totally, 56 projects are examined in this research.

The study projects have been classified here. This classification includes residential buildings, villas, added-storey, schools, administrative, commercial, fast-food, industrial structures, and LSF non-load-bearing walls. All the mentioned projects have been implemented in holy city of Mashhad or will be implemented in the future. Designers, administrators and employers are interviewed in person in all the above projects. The identified risks have been mentioned along with implemented stage of project.

\subsection{List of identified risks}

Table 1. List of identified risks

\begin{tabular}{llll}
\hline Number in Step & Risk Number & \multicolumn{1}{c}{ Risk } & Risk Step \\
\hline 1 & 1 & lack of foresight gas piping & Designing \\
\hline 2 & 2 & $\begin{array}{l}\text { lack of foresight of water-cooler } \\
\text { and air conditioning }\end{array}$ & Designing \\
\hline 3 & 3 & Disadvantage in flushing design & Designing \\
\hline 4 & 4 & cooling problem in large units & Designing \\
\hline 5 & 5 & Insufficient scientific support of & Designing \\
\hline 6 & & design bylaws & \\
\hline
\end{tabular}




\begin{tabular}{|c|c|c|c|}
\hline 7 & 7 & $\begin{array}{l}\text { consideration of bolted joints as } \\
\text { hinge }\end{array}$ & Designing \\
\hline 1 & 8 & $\begin{array}{l}\text { Incorrect implementation of water } \\
\text { transfer channel and its break } \\
\text { during heavy snow }\end{array}$ & Implementation \\
\hline 2 & 9 & $\begin{array}{l}\text { Incorrect implementation of water } \\
\text { transfer channel slope }\end{array}$ & Implementation \\
\hline 3 & 10 & Insulation core fire risk & Implementation \\
\hline 4 & 11 & $\begin{array}{l}\text { inconsistent implementation of } \\
\text { adhesion-type ceramic }\end{array}$ & Implementation \\
\hline 5 & 12 & $\begin{array}{l}\text { disadvantage in implementation } \\
\text { of flushing }\end{array}$ & Implementation \\
\hline 6 & 13 & $\begin{array}{l}\text { lack of occupational stability of } \\
\text { executive forces }\end{array}$ & Implementation \\
\hline 7 & 14 & $\begin{array}{l}\text { Lack of ranking of executive } \\
\text { contractors }\end{array}$ & Implementation \\
\hline 8 & 15 & Lack of specialized supervision & Implementation \\
\hline 1 & 16 & $\begin{array}{l}\text { lack of sense of structures' } \\
\text { strength (mental) }\end{array}$ & Operation \\
\hline 2 & 17 & Lack of staircase to the roof & Operation \\
\hline 3 & 18 & $\begin{array}{l}\text { Installation of heavy objects on } \\
\text { the wall }\end{array}$ & Operation \\
\hline 4 & 19 & $\begin{array}{l}\text { Implementation of walled ceramic } \\
\text { with glue }\end{array}$ & Operation \\
\hline 5 & 20 & Excessive heat inside the building & Operation \\
\hline 6 & 21 & $\begin{array}{l}\text { Breaking gypsum boards because } \\
\text { of students collision with wall }\end{array}$ & Operation \\
\hline 7 & 22 & $\begin{array}{l}\text { Tightening of the windows over } \\
\text { time }\end{array}$ & Operation \\
\hline 8 & 23 & $\begin{array}{l}\text { Disadvantage in the insulation of } \\
\text { dry facades }\end{array}$ & Operation \\
\hline
\end{tabular}




\begin{tabular}{llll}
\hline 9 & 24 & Dry facade being destructible & Operation \\
\hline 10 & 25 & Walls sound & Operation \\
\hline 11 & 26 & Sound insulation of walls & Operation \\
\hline 12 & 27 & windows poor sealing & Operation \\
\hline 13 & 28 & Cracking of wall in the place of & Operation \\
& & electricity tubes & Operation \\
\hline
\end{tabular}

\subsection{Classifying in terms of Implemented Step of Project}

According to table 1, the chart of risks percent in terms of project implemented step is outlined below.

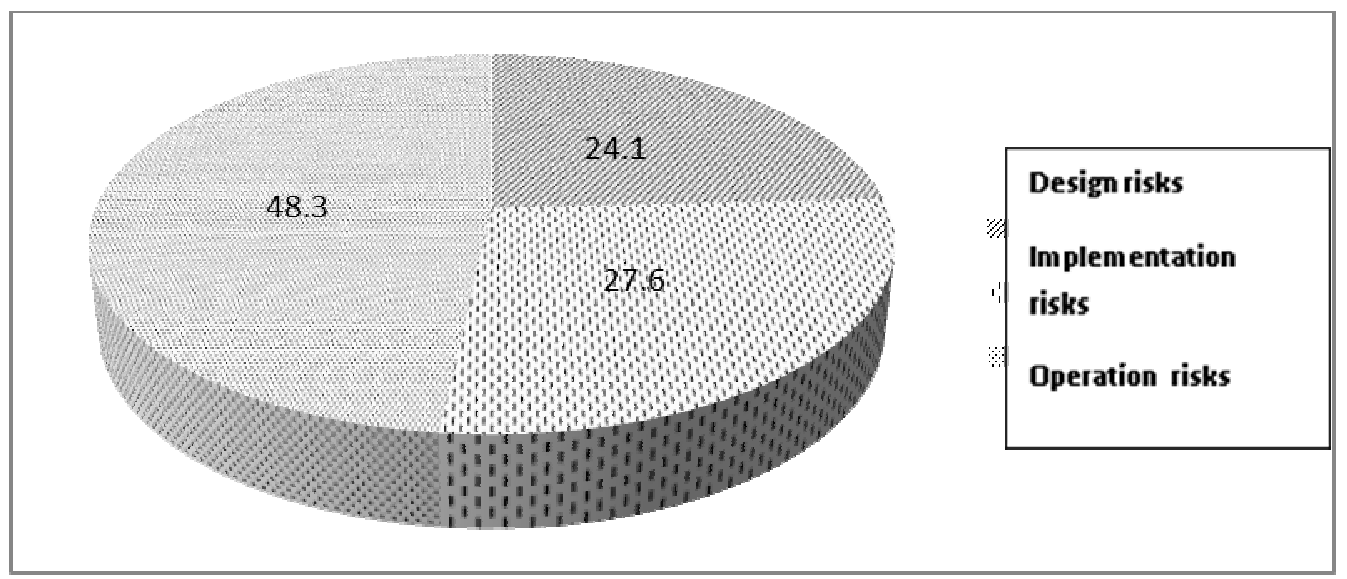

Fig.2. Contribution of each project implemented step from the Risks

\section{ASSESSMENT OF IDENTIFIED RISKS}

After applying of model on the data obtained from interviews, some calculated indices was obtained that using them made it possible the response to risk. These indices are arranged in table below. According to indices and table, the range of response to each risk is determined. 
Table 2. Amount of calculated indices of each risk determination of response range

\begin{tabular}{|c|c|c|c|c|c|}
\hline Risk & Risk Step & $\mathrm{RCN}$ & R.F & C.N & $\begin{array}{l}\text { Range of } \\
\text { Response }\end{array}$ \\
\hline $\begin{array}{l}\text { Unforecast of } \\
\text { Evaporative } \\
\text { cooler } \\
\text { and Vapor- } \\
\text { compression } \\
\text { refrigeration }\end{array}$ & designing & 45.66355 & 5.809806 & 4.1251 & 1 \\
\hline $\begin{array}{l}\text { too much heat } \\
\text { inside the } \\
\text { building }\end{array}$ & operation & 54.35 & 5.96 & 4.25739 & 1 \\
\hline $\begin{array}{l}\text { Unrating of } \\
\text { executive } \\
\text { contractors }\end{array}$ & implementation & 64.83 & 5.84 & 5.53297 & 1 \\
\hline $\begin{array}{l}\text { Implementation } \\
\text { of wall ceramic } \\
\text { with glue }\end{array}$ & operation & 69.37 & 6.59 & 4.00779 & 3 \\
\hline $\begin{array}{l}\text { Destruction of } \\
\text { dry view }\end{array}$ & operation & 70.75 & 5.84 & 6.00459 & 1 \\
\hline $\begin{array}{l}\text { Lack of } \\
\text { specialized } \\
\text { supervision }\end{array}$ & implementation & 75.87 & 5.85 & 6.19004 & 1 \\
\hline $\begin{array}{l}\text { Unforcasting of } \\
\text { gas pipe }\end{array}$ & designing & 79.25355 & 7.54833 & 3.98481 & 2 \\
\hline $\begin{array}{l}\text { Lack of } \\
\text { executive } \\
\text { forces' job } \\
\text { stability }\end{array}$ & implementation & 84.18 & 5.94 & 6.76538 & 1 \\
\hline $\begin{array}{l}\text { Insufficient } \\
\text { scientific }\end{array}$ & designing & 85.47 & 7.76 & 3.31195 & 2 \\
\hline
\end{tabular}




\begin{tabular}{|c|c|c|c|c|c|}
\hline $\begin{array}{l}\text { backing of } \\
\text { design } \\
\text { regulations }\end{array}$ & & & & & \\
\hline $\begin{array}{l}\text { Limitations of } \\
\text { building } \\
\text { designing }\end{array}$ & designing & 85.53 & 7.43 & 3.88669 & 2 \\
\hline $\begin{array}{l}\text { No stairs to the } \\
\text { roof }\end{array}$ & operation & 91.82 & 6.87 & 5.21642 & 2 \\
\hline $\begin{array}{l}\text { Poor water } \\
\text { stopping of } \\
\text { windows }\end{array}$ & operation & 98.90 & 7.55 & 3.92066 & 3 \\
\hline $\begin{array}{l}\text { Cracking walls } \\
\text { in tubes }\end{array}$ & operation & 111.62 & 6.89 & 5.76159 & 3 \\
\hline $\begin{array}{l}\text { Considering } \\
\text { fitting bolts in } \\
\text { detail }\end{array}$ & designing & 113.86 & 7.60 & 4.72542 & 2 \\
\hline $\begin{array}{l}\text { Lack of } \\
\text { endurance of } \\
\text { structures }\end{array}$ & operation & 115.5007 & 7.980135 & 3.8647 & 2 \\
\hline $\begin{array}{l}\text { Cooling } \\
\text { problem in larg } \\
\text { units }\end{array}$ & designing & 117.5333 & 8.00 & 3.84912 & 3 \\
\hline
\end{tabular}

\begin{tabular}{|c|c|c|c|c|c|}
\hline $\begin{array}{l}\text { Wrong } \\
\text { implementation } \\
\text { of water } \\
\text { transferring } \\
\text { and breaking it } \\
\text { when snowing }\end{array}$ & implementation & 123.21 & 7.81 & 4.45963 & 3 \\
\hline $\begin{array}{l}\text { Inconsistent } \\
\text { implementation } \\
\text { of ceramic glue }\end{array}$ & implementation & 124.70 & 7.21 & 5.68845 & 3 \\
\hline $\begin{array}{l}\text { Error in } \\
\text { designing of }\end{array}$ & designing & 128.5246 & 7.396462 & 5.54156 & 3 \\
\hline
\end{tabular}




\begin{tabular}{|c|c|c|c|c|c|}
\hline flushing & & & & & \\
\hline $\begin{array}{l}\text { Implementation } \\
\text { of wrong } \\
\text { channel of } \\
\text { water } \\
\text { transferring }\end{array}$ & implementation & 130.08 & 7.77 & 4.70483 & 3 \\
\hline $\begin{array}{l}\text { Hardening of } \\
\text { windows over } \\
\text { the time }\end{array}$ & operation & 148.19 & 8.18 & 4.57594 & 3 \\
\hline $\begin{array}{l}\text { Sounding of } \\
\text { walls }\end{array}$ & operation & 150.15 & 8.05 & 5.41486 & 3 \\
\hline $\begin{array}{l}\text { Error in } \\
\text { implementation } \\
\text { of flushing }\end{array}$ & implementation & 163.79 & 7.52 & 6.76278 & 3 \\
\hline $\begin{array}{l}\text { Error in } \\
\text { insulation of } \\
\text { dry facades }\end{array}$ & operation & 165.42 & 8.38 & 4.6666 & 3 \\
\hline $\begin{array}{l}\text { Cracking the } \\
\text { plaster leaves } \\
\text { by colliding } \\
\text { with the } \\
\text { students }\end{array}$ & operation & 178.05 & 8.53 & 4.8689 & 3 \\
\hline $\begin{array}{l}\text { Sound } \\
\text { insulation of } \\
\text { walls }\end{array}$ & operation & 178.55 & 8.60 & 4.6666 & 3 \\
\hline $\begin{array}{l}\text { Destruction of } \\
\text { insulation In } \\
\text { added floor } \\
\text { projects }\end{array}$ & operation & 180.31 & 7.93 & 6.06954 & 3 \\
\hline $\begin{array}{l}\text { Risk of Core } \\
\text { insulation fire }\end{array}$ & implementation & 188.38 & 8.05 & 6.41326 & 3 \\
\hline $\begin{array}{l}\text { Installing the } \\
\text { heavy objects }\end{array}$ & operation & 271.52 & 8.46 & 7.40946 & 3 \\
\hline
\end{tabular}


on the wall

\section{REACTION TO RISK}

As it mentioned in section 3-2, it can be determined the risk response strategy based on RF and $\mathrm{CN}$ indecis. According to the figure, it's been specified three areas to respond to the risks that each area of risk has been determined in table 3 .

\begin{tabular}{lllll}
\hline Row & All risks & Risks of Area 1 & $\begin{array}{c}\text { Risks of } \\
\text { Area 2 }\end{array}$ & Risks of Area 3 \\
\hline Number & 29 & 6 & 6 & 17 \\
\hline Percent & 100 & 20.69 & 20.69 & 58.62 \\
\hline
\end{tabular}

Data in table 3 has been specified on diagram 2.

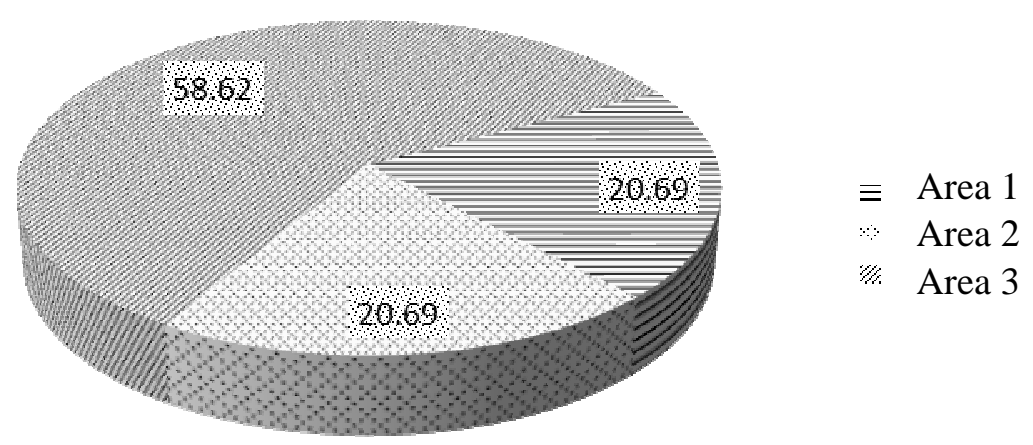

Fig.3.Contribution of each area of Risks

\section{CONCLUSION}

In this study, the risk management process on LSF structures was performed in designing, implementation and operation steps. The applied method is based on fuzzy theory and FMEA 
technique. In this model, three criteria: cost, time and quality are relative priority. The value of these criteria is determined through the questionnaire by respondents.

After applying the model on the data obtained from interviews, calculated indices for each risk was obtained that made it possible the response process to risk.

According to the obtained data, the list of identified risk based on RCN that indicates the importance of risk, was arranged.

This study showed that 20.69 percent of risks were acceptable and 20.69 percent of risks were portable. Also 58.62 percent of risks must have been reduced or prevented.

This study can be used in project managers' decision-making for selection of project implementation system and also forecasting the effective potential risks.

\section{REFERENCES}

[1] Designing and implementation of steel cold-rolled construction by-law (structure section), Journal, 612.

[2] Mahdavi N.M.J., Hajian M, Doroodgar A. Role of LSF technology in economic housing for urban Sustainability; case of Iran, Procedia Engineering., 2011.

[3] Oliveira F, Mendonça P, Couto J.P, Camões A. Environmental impact and comparative economic analysis among different building constructive systems used in Portugal , Recent Advances in Environmental Science and Biomedicine, 8th International Conference on Energy and Development., 2014.

[4] Yegane A, Momtazdargahi M.S, Shariatmadari H, Gerami M. Studying LSF and steel structures in terms of cost, time and quality, civil international conference, architecture and urban infrastructure., 2015.

[5] Taroun A. Towards a better modeling and assessment of construction risk: Insights from a literature review, International Journal of Project Management., 2012.

[6] Mohammad A M, Al-Bahar J.F. Project Risk Analytic Assessment Using the Hierarchy Process, IEEE Transactions on Engineering Management., 1990.

[7] Light Steel Framing Architectural Design Guide, Canadian Sheet Steel Building Institute.

[8] Ariyanayagam A.D, Mahendran M. Numerical modeling of load bearing light gauge steel frame wall systems exposed to realistic design fires, Thin-Walled Structures., 2014.

[9] Gerami M, Lotfi M, Roya N. Inelastic behavior of cold-formed braced walls under monotonic and cyclic loading, International Journal of Advanced Structural Engineering (IJASE)., 2015. 
[10]Enrico de Angelis, Ermanno S, Light steel-frame walls: thermal insulation performances and thermal bridges , Energy Procedia., 2014.

[11] Mohsen A. Identification and assessment of risk in high way construction projects, MA Thesis, Amir Kabir University, Civil and environment Faculty., 2013.

\section{How to cite this article:}

Yegane A and Shariatmadari H. Risk managment in Lsf structures (identifying, assessment, responding). J. Fundam. Appl. Sci., 2016, 8(2S), 163-174. 